\title{
On the Channels of Entrepreneurship Education for University Students
}

\author{
Sen LIN \\ School of Information Science and Engineering, Wuhan University of Science and Technology, Wuhan, China
}

\begin{abstract}
Since the expansion of higher education, university graduates have been confronted with more intense competition in the job market, thus it is necessary for them to renew their concept of hunting and choosing a job and for universities to implement the entrepreneurship education. This paper elaborates the significance and the necessity of entrepreneurship education, proposes three channels to strengthen it based on the analysis of its status quo and concludes that the employment situation will get better, thereby achieving the goal of building the harmonious society.
\end{abstract}

KEYWORD: University Students; Employment Situation; Entrepreneurship Education; the Scientific Concept of Development

With the expansion of colleges and universities enrollment in China in 1999, until 2003, it is the first year of the China's college enrollment expansion of students finished their undergraduate courses, the total of national college graduates were 2,122,000, 670,000 more than in 2002 , and the increase is $46.2 \%$; in 2004 , the total of national college graduates were $2,800,000$ people, 680,000 more than in 2003; in 2005 the total of national college graduates reached 3,380,000 people. More than 580,000 people in 2004, with an increase of $20.71 \%$; in 2006, this number is $4,130,000$ college graduates, 750,000 more than in 2005, with an increase of $22.19 \%$... Until 2009, the graduating students will reach $6,110,000$, with increasing at a geometric rate of total university graduates in the few years. Because of that, the college students' employment situation was grim year after year. Especially in 2009, affected by the global economic crisis, China's GDP growth in this year maintain the rate remained above $8 \%$ is very difficult, according to another source, only if the growth rate of GDP more than $10 \%$ annually, could China created enough jobs to meet a huge number of graduates needs. It will cause considerable of unemployment and enormous awaiting job assignment if the GDP decrease $1 \%$. At the present, the number of students 4,950,000 and 5,600,000 which graduated in 2007 and 2008 respectively, 1,000,000 people and 1,500,000 people of this could not find a job; therefore, the employment situation of college student who graduated in 2009 years was a huge challenge toward themselves.

Under such circumstances, colleges and universities should solve the problem of the students' employment fundamentally and enhance college students' employment competitiveness. In addition to innovating the mechanism of existing personnel use and evaluation, it is a must for these college graduates to renew the employment concept and career choice, and replace the passive employment with starting business independently. Above that, the implementation of entrepreneurship education towards the undergraduate students is of the general trend.

\section{THE MEANING OF THE ENTREPRENEURSHIP EDUCATION}

"At the end of 1980s, the UNESCO, in the Trend of International Education Development Seminar in 21 st Century, put forward the "third passport" of learning, namely, "entrepreneurship education" or Enterprise Education. UNESCO pointed out that entrepreneurship education aims at cultivating pioneering personnel in the broad sense. Entrepreneurship education is very important for the cultivation of personal initiative, the spirit of adventure, the abilities of entrepreneurship, independent work and the technical, social and managerial skills. UNESCO required universities to make entrepreneurial skills and entrepreneurship as the basic goal of higher education, to enhance it to 
the same status of academic research and vocational education [1]p12." In essence, entrepreneurship education refers to the education to cultivate students' awareness, quality and skills of entrepreneurship, that is, teaching students how to adapt to the social life, improving the ability, and cultivating the method and the channels of selfentrepreneurship. Entrepreneurship Education in college students is in fact part of college students' quality education and innovation education. And it is a long-term plan to adapt to the development of knowledge economy, to increase the students' employment chances and to construct of national innovation system. Besides, it is the expansion of the functions of higher education.

\section{THE NECESSITY OF ENTREPRENEURSHIP EDUCATION}

It is indispensable for colleges and universities To cultivate creative and innovative talents. Guiding students to carry out entrepreneurial activities could promote the development of productive forces directly; training the students to form the quality of entrepreneurship also boost the development of productive forces indirectly. Therefore, colleges and universities should stand in the height of history in the twenty-first Century, highlighting and carrying out actively the entrepreneurship education of University students.

\subsection{Entrepreneurship education is the need of the development of the times}

Entrepreneurship education has become a new trend of modern education development and reform in the world. Many developed countries, such as the USA and Japan have higher rate of entrepreneurship. A very important reason is that their scientific development of entrepreneurship education. According to the experience of economically developed countries, entrepreneurship education should be incorporated into the national education system and lifelong education system. Entrepreneurship Education in the United States has been incorporated into the national education system and has formed a set of more scientific and perfect teaching and researching system of entrepreneurship education until now. Since 1998, the Ministry of Education and Ministry of International Trade and Industry in Japan began to implement the "employment and entrepreneurship education" in the elementary school, cultivating school children to develop psychological awareness and willpower of employment and entrepreneurship. And in 1966 India has put forward the concept of "selfemployment education" to encourage college graduates to support themselves.

\subsection{Entrepreneurship education is the need of the development of our country}

"Being impacted by the financial crisis, the serious situation of graduates' employment is obvious. According to the forecast, until 2030s, the labor population in China will maintain above $60 \%$ of the proportion in the total. Under such heavy employment pressure, it is very important for college graduates to change the employment concept and for the school to strengthen the entrepreneurship education, and to guide the graduates to set up their own business. These are also the constant healthy development of college enrollment. If the large number of graduates after enrollment expansion cannot successfully gain employment, it will in turn constrain the development of expansion and thus impede the pace of China's higher education from elite education to mass education.’[2]p8

\subsection{Entrepreneurship education is the requirement of quality education}

In "The Decision of Deepening Educational Reform and Promoting Quality Education Comprehensively" issued by the CPC Central Committee and State Council, there is such an important instructions: set entrepreneurship education as the main content of education reform, and set the cultivation of students with entrepreneurial spirit, entrepreneurial ability as the goal of education development. The former General secretary $\mathrm{Hu}$ Jintao, in the speech titled "Hold high the great banner of socialism and struggle in order to win new victories in building a moderately prosperous society", pointed out that, the party committees and governments at all levels and education, personnel and other relevant departments must go all out to solve the problem of employment and entrepreneurship of University graduates. Making full use of so many college graduates will produce a strong labor force in our country.

\section{THE CURRENT SITUATION OF ENTREPRENEURSHIP EDUCATION}

Entrepreneurship education, as an education concept, was first formally presented by Colin Bohr. In the popularity of Entrepreneurship education today, the United States, Japan, the United Kingdom and many other countries have formed a pretty mature system of Entrepreneurship education and support. Compared with developed countries, the Entrepreneurship education in our country has a late start in the stage of introduction, absorption and the exploration of localized education in course development, theory and method research of entrepreneurship education. The entrepreneurship education of our country has been started since the initiative exploration of entrepreneurship education 
in some colleges and universities. At the beginning of 2002, the Ministry of education selected Tsinghua University and other 9 universities as experimental institutions, and since then college students' entrepreneurial activities have been in its full swing. Up to now, the entrepreneurship education has been implemented in many universities around the country, and an increasing number of college graduates join the self-employed group, becoming attractive highlights among the wave of selfemployment. But only a fraction of college students achieve success in entrepreneurship.

"According to recent situation, the entrepreneurship education in our country is in the initial stage and at the low level, thus having many objective problems in the process of its development. Firstly, the disciplinary basis of entrepreneurship education in our country is quite poor. Since it was introduced into our country in the 1980s, it had certain development only confined to some key universities. Secondly, the awareness of selfemployment among college students is not enough. According to current ideology situation of college teachers and students, the problem lies in the inadequate understanding."[3]p25 Some college teachers hold the idea that self-employment only applies to certain group of students equipped with high grades and creative abilities. While some college students think that the exact one thing they need to do on campus is to manage the study of professional knowledge and that there is no need to have entrepreneurship education. This kind of thoughts definitely hinders the development of entrepreneurship education in college. Thirdly, there is a bad need of the faculty of entrepreneurship education, who are required to be armed with a certain number of theoretical knowledge and entrepreneurship experience as well. Thus, if the teacher doesn't experience in person and just repeats what the books say during the process of teaching, it is impossible for him to grasp the essence of entrepreneurship, let alone teaching the students to start business by themselves.

\section{THE CHANNELS OF ENTREPRENEURSHIP EDUCATION}

It is a pioneering task for university students to start their own business, which needs supports from all aspects, especially the supports of family and society. Therefore, each university should regard the Scientific Concept of Development as the theoretical guidance, innovate ideological and political education system in universities by combining class education and practice, set up the idea of individualized education with the concept of people first, motivate the potential individuality and creative ability of university students, give full play to all aspects of specialty and potential, and improve their core competence of university students, in order to and reach the goal of university students starting their own business.

\subsection{Guided by the scientific concept of development}

Stick to educating and equipping the university students with the great theoretical and innovative achievement of Marxism with Chinese features. It is the necessity of ideological and political education to help university students to set correct world view, life outlook and value is, and also a valuable experience to make effective achievements in university since reform and opening-up. Peopleoriented, comprehensive, balanced and sustainable scientific development view, presented by our Communist Party, is the latest theoretical and innovative achievements of Marxism with Chinese features. Scientific development view, featured with bright time characteristic, scientific concept, rich connotation and clear theoretical context, has built a scientific system regarding development as the primary task, "people-oriented" idea the core, comprehensive, balanced and sustainable development the basic requirements and the overall consideration as the fundamental method. Scientific development view, the epitome to guide the development of the Marxist world outlook and methodology, provides the university students with scientific method and theoretical guidance of deepen ideological and political education. Considering scientific development view as the guide of entrepreneurship education for university students is not only the necessity for education but also the demand for enhancing colleges' overall qualities and promoting the harmonious development between colleges and society.

\subsection{Combine class teaching with practice}

Entrepreneurship education in class mainly includes teaching basic entrepreneurial knowledge, primary quality and fundamental skills, focuses on developing the awareness of self-employment among university students, forms the knowledge structure essential in starting one's own business, improves the self-employed quality and ability of university students, inspires students' innovative thinking and development of innovation. Besides, practice is needed to cement what have been learned in class. Only by practical entrepreneurial training can students' entrepreneurial quality and ability be improved comprehensively.

\subsection{Set up platform of entrepreneurship at university}

Some students who want to start their own 
businesses may not succeed. The reason is not lacking of self-employment skills, but the shortage of experience on achievement transformation and product development which have close link with entrepreneurship education. Therefore, what we should do is bringing the university education, scientific research and industry development together, thus realizing the exact integration of producing, learning and researching. And we should create conditions for the realization of multiple social function of university and begin to give college students substantive business platform. For example, students entrepreneurial region should be built on campus, flea market can be organized and so on. Meanwhile, the potential business plan should be provided with a good business environment and practical conditions, namely, giving financial aid, practice area and much other assistance. As a consequence, the entrepreneurial ability of college students will comprehensively promoted under such risk.

\section{THE GOAL OF ENTREPRENEURSHIP EDUCATION}

Entrepreneurship education among university students aims to not only train and form the basic entrepreneurial quality of young students but also to cultivate talents with entrepreneurial sense, entrepreneurial psychological quality, entrepreneurial ability and comprehensive entrepreneurial knowledge, in order to adapt to the demand of talents' quality in economic society.

Entrepreneurship education, turning the employment into self-employment, solves the current predicament of employment, and then drives the wave of employment, making the whole employment situation in society a bright prospect and reaching the goal of building a harmonious society in our country.

\section{REFERENCES}

[1] Li Guiming. "Improve students' ability to entrepreneurship and entrepreneurial ways and measures analysis". Education Exploration, 2004, (5).

[2] Nie Ying. "Entrepreneurship education of institutions of higher learning". Liaoning Education Research, 2005, (3).

[3] Zhang Fan. "Present situation and problems of the college students' entrepreneurship education in our country". Education Science \& Culture, 2007, (20). 